Jurnal Akuntansi dan Investasi, Vol. 18 No. 1, Hlm: 13-27, Januari 2017

Artikel ini tersedia di website: http://journal.umy.ac.id/index.php/ai

DOI: $10.18196 /$ jai.18158

\title{
Pengaruh Tindakan Supervisi, Kompleksitas Tugas dan Profesionalisme Auditor terhadap Kepuasan Kerja Auditor
}

\author{
Hasanati'; Akram²; M. Irwan ${ }^{2}$ \\ 'Inspektorat Kab Sumbawa Barat, Jl. Kuang, Taliwang, Kabupaten Sumbawa Barat, NTB, Indonesia \\ ${ }^{2}$ Program Magister Akuntansi Universitas Mataram, Jl. Pemuda No. 35 Mataram, NTB, Indonesia

\begin{tabular}{l}
\hline A R T I C L E I N F O \\
\hline Article history: \\
received 15 Nov 2015 \\
revised 25 Jul 2016 \\
accepted 27 Okt 2016 \\
Keywords: \\
Supervisory Action; \\
Task Complexity; \\
Professionalism; \\
Job Satisfaction
\end{tabular}

\begin{abstract}
A B S TRACT
This study aims to examine and find the empirical evidence the effects of Supervisory Action, Task Complexity, and Auditor's Profesionlism toward Auditor's Job Satisfaction. The samples of this study are the Internal Control Officers (APIP) in Regional Inspectorate in Sumbawa Island, Nusa Tenggara Barat Province. Total sample are 81 which consists of 50 Auditor Officers (JFA) dan 31 Control Officers (P2UPD) whose as member in audit team, selected by using sampling technique of purposive sampling. The research results showed that Supervisory Action and Task Complexity have positive significant influence on Auditor's Satisfaction. This study also find evidence that Auditors' Professionalism
\end{abstract} \\ able to effects Job Satisfaction negatively. \\ (C) 2017 JAI. All rights reserved
}

\section{PENDAHULUAN}

Pengawasan intern dibutuhkan untuk mengoptimalkan kinerja satuan kerja pada sektor pemerintahan. Pentingnya peranan pengawasan intern disebutkan dalam Peraturan Menteri Pendayagunaan Aparatur Negara Nomor 5 tahun 2008 (Permenpan No.5/2008) tentang standar audit Aparat Pengawasan Intern Pemerintah (APIP), bahwa melalui pengawasan intern dapat diketahui apakah suatu instansi pemerintah telah melaksanakan kegiatan sesuai dengan tugas dan fungsinya secara efektif dan efisien, serta sesuai dengan rencana, kebijakan yang telah ditetapkan, dan ketentuan. Selain itu, Permenpan No.5/2008 menambahkan bahwa pengawasan intern atas penyelenggaraan pemerintahan diperlukan untuk mendorong terwujudnya good governance dan clean government dan mendukung penyelenggaraan pemerintahan yang efektif, efisien, transparan, akuntabel serta bersih dan bebas dari praktik korupsi, kolusi, dan nepotisme.

Harapan pelaksanaan fungsi pengawasan intern secara efektif dan efisien terbentur dengan rendahnya level kapabilitas pengawasan APIP saat ini. Hal ini menjadi salah satu fokus Pemerintah untuk segera diatasi. Berdasarkan hasil penilaian Internal Audit Capability Model (IACM) yang dilakukan Badan Pengawasan Keuangan dan
Pembangunan (BPKP) pada akhir tahun 2014, khusus untuk Inspektorat di Provinsi NTB menunjukkan bahwa kapabilitas pengawasan Inspektorat sepulau Sumbawa menempati kapabilitas pengawasan terendah, yaitu level 1. Sementara level kapabilitas Inspektorat sepulau Lombok berada pada level 2, kecuali Inspektorat Kota Mataram masih berada pada level 1 (Laporan BPKP cabang Provinsi NTB, 2015).

Salah satu strategi yang diterapkan Pemerintah untuk mempercepat perbaikan rendahnya level kapabilitas pengawasan APIP tersebut adalah dengan menerapkan paradigma audit baru (Warta Pengawasan, 2013). Peran auditor dalam paradigma audit baru tidak lagi sebagai watchdog (pengawas) namun diarahkan sebagai partner auditan yaitu konsultan dan katalis. Jika sebelumnya kinerja APIP menitikberatkan pada jumlah temuan, maka pada paradigma audit baru, jumlah temuan bukan lagi tolak ukur bagus tidaknya kinerja suatu APIP. APIP lebih dituntut untuk mampu memberikan nilai tambah dan membantu auditan mengenali resiko-resiko yang akan menghambat perbaikan kinerja auditan.

Pelaksanaan paradigma audit baru bukanlah perkara mudah. Auditor internal yang selama bertahun-tahun terbiasa dengan paradigma audit lama, tentu membutuhkan proses penyesuaian diri. Perubahan peran auditor internal dari 
watchdog menuju konsultan dan katalis yang diperkuat dengan tuntutan penerapan audit kinerja, membutuhkan perubahan metode, prosedur, dan komunikasi audit yang digunakan. Hal ini tentu saja akan menambah beban kerja atasan dalam memberikan supervisi terhadap anggota timnya. Selain itu, kompleksitas dan profesionalisme yang akan dihadapi auditor juga akan meningkat. Fenomena ini dapat menjadi tekanan psikologis bagi tim auditor internal, yang kemungkinan berdampak pada menurunnya semangat kerja untuk menyelesaikan tugas audit yang dijalani.

Pada situasi seperti yang dijelaskan di atas, dibutuhkan kerjasama antara tim audit dan supervisor untuk membentuk tim audit yang solid, sehingga mampu menyelesaikan tugas audit. Supervisor selaku atasan/pimpinan baik bagi tim audit maupun organisasi secara keseluruhan tentu memiliki beban yang lebih berat. Atasan harus memikirkan bagaimana cara memberikan tindakan supervisi agar tim auditnya dapat menjalankan peran konsultan dan katalis secara baik, dan juga merubah cara pandang tim auditnya bahwa kompleksitas dan profesionalisme merupakan daya tarik dari tugas audit.

Kesuksesan atasan memotivasi dan memberikan tindakan supervisi yang efektif tergantung pada pemahaman tentang perilaku tim auditnya. Gibson et al. (2008) mengemukakan masingmasing manusia berbeda, mempunyai keunikan persepsi, kepribadian, dan pengalaman hidup. Manusia berbeda latar belakang etnis, kemampuan belajar, dan tingkat aspirasi yang berbeda. Menurut As'ad (2012) tentang poin penting teori hirarki kebutuhan Maslow bahwa setiap individu mempunyai kebutuhan, dorongan, faktor instrinsik dan ekstrinsik yang timbul sesuai dengan kepentingan individu tersebut. Mengacu pada dua argument tersebut, untuk mencapai pelaksanaan tugas yang efektif, maka atasan suatu organisasi harus memandang masing-masing karyawan atau anggota sebagai sosok yang memiliki keunikan perilaku dan kultur serta memiliki kebutuhan yang berbeda. Ini artinya, seorang pimpinan perlu menyelaraskan emosinya dengan emosi bawahannya. Jika pemimpin tidak beresonansi, bisa saja anggota organisasi hanya melakukan pekerjaan dengan "cukup baik" tetapi tidak memberikan yang terbaik. Tanpa hati yang memadai, seorang pemimpin bisa mengelola tetapi tidak memimpin (Goleman et al., 2006).

Goleman et al. (2006) menambahkan menurut penemuan baru tentang kepuasan kerja, emosi yang dirasakan orang ketika bekerja akan secara langsung mencerminkan kualitas yang sesungguhnya dari kehidupan kerjanya. Saari dan Judge (2004) mengemukakan karyawan mempunyai perilaku atau pandangan tentang banyak aspek mengenai pekerjaannya, karirnya, dan organisasinya. Akan tetapi, dari perspektif praktik dan penelitian, sebagian besar perilaku karyawan tercemin dari kepuasan kerja. Kepuasan kerja merupakan kombinasi dari psikologi dan lingkungan yang menyebabkan seseorang yakin untuk mengatakan puas atas pekerjaannya (Hoppock, 1935).

Selanjutnya, Robbins (2002) mengemukakan seseorang dengan tingkat kepuasan kerja yang tinggi mempunyai sikap positif terhadap pekerjaannya, sebaliknya jika seseorang tidak puas dengan pekerjaannya mempunyai sikap negatif terhadap pekerjaannya. Ini artinya, suasana hati yang baik membuat seseorang memandang segala hal yang ada disekelilingnya dengan cara yang positif sehingga menimbulkan rasa optimis akan kemampuannya untuk mencapai tujuan. Selain itu, kepuasan kerja merupakan faktor kritis untuk dapat tetap mempertahankan individu yang berkualifikasi baik (Agustia, 2009). Menurut Murtanto dan Djasmin (2005) kepuasan kerja merupakan faktor penting yang berperan dalam mempengaruhi kepuasan hidup. Meskipun dengan tekanan dan resiko yang tinggi, selama puas dengan organisasi, tentu membuat seseorang berbuat maksimal.

Menurut Syofyetty (2009) tindakan supervisi diperlukan agar dapat memotivasi para auditor dibawahnya untuk memperoleh kepuasan kerja auditor sehingga dapat menghasilkan temuan pemeriksaan yang berkualitas. Boiman et al. (2013) mengemukakan pelaksanaan supervisi pada internal audit merupakan salah satu bagian yang sangat pokok untuk mendukung aktivitas organisasi. Oleh karenanya, anggota staf audit internal harus disupervisi secara tepat sehingga dapat melaksanakan tanggungjawabnya secara layak. Menurut Yusralaini et al. (2011) pelaksanaan audit dilaksanakan secara tim untuk memudahkan pemecahan permasalahan yang ditemukan. Pada kondisi ini kehadiran supervisor menjadi bagian penting dalam mencapai hasil yang maksimal dari suatu permasalahan yang dialami dalam proses audit.

Murtanto dan Djasmin (2005) serta Yusralaini et al. (2011) menemukan bukti empiris bahwa dari tiga aspek pembentuk tindakan supervisi yaitu aspek kepemimpinan dan mentoring, 
aspek kondisi kerja, dan aspek penugasan, hanya aspek kondisi kerja yang berpengaruh terhadap kepuasan auditor. Namun, Boiman et al. (2013) menyimpulkan bahwa bukan hanya aspek kondisi kerja, tetapi aspek penugasan juga mampu mempengaruhi kepuasan kerja auditor. Selanjutnya, Hadi (2007) menemukan bahwa hanya aspek kepemimpinan dan mentoring yang berpengaruh positif terhadap kepuasan auditor. Sementara Syofyetty (2009) menemukan bukti empiris bahwa aspek kepemimpinan dan monitoring, aspek kondisi kerja serta aspek penugasan berpengaruh terhadap kepuasan kerja auditor.

Berbeda dengan beberapa penelitian sebelumnya yang disebutkan di atas, penelitian ini mencoba menguji faktor kompleksitas dalam kaitannya dengan kepuasan kerja auditor di Inspektorat. Pengujian atas pengaruh faktor kompleksitas tugas dalam melakukan audit penting dilakukan karena tugas melakukan audit adalah tugas yang banyak menghadapi persoalan kompleks. Selain kompleks, pekerjaan auditor tidak kenal waktu, selalu dengan tingkat kesibukan waktu yang sangat tinggi (Fitriany et al., 2011). Menurut Folami dan Bline (2012) kompleksitas tugas merupakan salah satu variabel yang secara konsisten berhubungan dengan kepuasan kerja. Jika kompleksitas tugas audit dihubungkan dengan kepuasan kerja auditor, maka tugas audit harus dibuat menarik.

Pradipta (2013) menemukan bukti empiris kompleksitas tugas berpengaruh terhadap kepuasan kerja auditor. Kompleksitas tugas memberikan tantangan bagi akuntan untuk terus bekerja dan memberikan kepuasan kerja. Selanjutnya, Dewi dan Sukirno (2013) menyimpulkan penugasan menjadi hal yang biasa bagi auditor, tetapi semakin banyak dan kompleknya tugas yang diberikan, maka akan berdampak pada menurunnya kepuasan kerja yang dirasakan auditor. Sementara itu, Fitriany et al. (2010) tidak menemukan adanya pengaruh kompleksitas tugas terhadap kepuasan kerja auditor. Kompleksitas tugas sudah menjadi nature dari pekerjaan audit sehingga tidak mempengaruhi kepuasan kerja auditor.

Pekerjaan audit merupakan pekerjaan yang menyangkut kepentingan publik sehingga setiap auditor perlu menjunjung tinggi profesionalismenya. Agustia (2007) menyimpulkan seorang yang profesional adalah seseorang yang (1) percaya bawha pekerjaannya adalah penting; (2) memberikan jasa bagi kepentingan publik; (3) memerlukan otonomi sebagai syarat bagi jasajasanya; (4) mendukung peraturan sendiri yang berbeda dengan aturan profesi yang lain; dan (5) berafiliasi dengan anggota-anggota lainnya dalam profesinya. Menurut Dali dan Mas'ud (2014) semakin tinggi profesionalisme auditor maka semakin tinggi pula kepuasan kerjanya, karena profesionalisme merupakan kunci sukses para auditor internal dalam menjalankan tugas audit. Putri (2011), Hernawati (2008), dan Agustia (2007) juga menemukan bukti empiris bahwa profesionalisme mampu mempengaruhi kepuasan kerja auditor. Sementara Aditya dan Wirakusuma (2014) menemukan bukti empiris bahwa komitmen profesional tidak berpengaruh terhadap kepuasan kerja. Hal ini disebabkan karena komitmen profesional sangat dipengaruhi oleh organisasi tempat auditor bekerja.

Berangkat dari berbagai temuan penelitian terdahulu yang masih menemukan hasil tidak konsisten, maka penelitian ini akan kembali menguji faktor-faktor yang berpengaruh terhadap kepuasan kerja auditor dengan mengadopsi penelitian Syofyetty (2009). Namun, berbeda dengan penelitian Syofyetty (2009), penelitian ini dilakukan dengan beberapa pengembangan, yakni: pertama, sampel penelitian adalah auditor internal yang menjadi anggota tim audit pada Inspektorat se-Pulau Sumbawa di Provinsi NTB. Kedua, jika penelitian terdahulu menguji aspek pembentuk tindakan supervisi sebagai variabel yang terpisahpisah, maka penelitian ini mencoba mengusulkan konsep bahwa tindakan supervisi merupakan satu variabel yang utuh. Ketiga, adanya tambahan variabel kompleksitas dan profesionalisme auditor juga merupakan kebaruan penelitian ini dari penelitian Syofyetty (2009). Selain itu, penggunaan Partial Least Square (PLS) sebagai alat analisis diharapkan memberikan hasil analisis yang lebih detail terkait model penelitian yang digunakan.

Penelitian ini perlu dilakukan untuk mengetahui keterkaitan tindakan supervisi, kompleksitas tugas, dan profesionalisme auditor terhadap kepuasan kerja auditor dengan menggunakan konsep teori hirarki kebutuhan Maslow. Hasil penelitian ini dapat membantu pimpinan dalam memotivasi tim auditornya guna membentuk tim audit yang solid sehingga mampu meningkatkan kapabilitas pengawasan organisasi yang dipimpin.

Kontribusi hasil penelitian ini diharapkan dapat menambah literatur penelitian dibidang perilaku auditor terkait kepuasan kerja auditor, khususnya auditor di level inspektorat pemerintah daerah. Selain itu, hasil penelitian ini diharapkan dapat memberi masukan tentang faktor-faktor yang mempengaruhi kepuasan kerja sehingga supervisor/pimpinan organisasi dapat merumus- 
kan cara/strategi peningkatan semangat kerja auditor yang dampaknya pada perbaikan kapabilitas pengawasan APIP. Kontribusi bagi pengambil kebijakan dapat menyusun bentuk kebijakan tentang peningkatan kepuasan kerja auditor sehingga mampu mempertahankan minat pegawai untuk tetap menjadi auditor intenal pemerintah.

\section{TINJAUAN LITERATUR DAN PERUMUSAN HIPOTESIS}

\section{Teori Hirarki Kebutuhan Maslow (1954)}

Teori hirarki kebutuhan pertama kali dirumuskan oleh Maslow (1954). Menurut Maslow (1954) sebagaimana dikutip As'ad (2012) menyebutkan bahwa kebutuhan individu dapat disusun dengan cara hierarki. Kebutuhan tersebut digolongkan dalam lima tingkatan, mulai dari tingkat yang paling dasar hingga tingkat yang paling tinggi yang meliputi: (1) Kebutuhan biologis; (2) kebutuhan akan keamanan saat bekerja; (3) kebutuhan akan penerimaan, penghargaan, prestasi dan keterlibatan dalam lingkungan tempatnya berada; (4) kebutuhan akan harga diri; dan (5) kebutuhan akan keinginan untuk berbuat yang lebih baik.

Konsep teori hirarki kebutuhan Maslow (1954) menyebutkan bahwa pemenuhan tiap tingkat kebutuhan tergantung pada kepentingan tiap individu. Menurut Luthans (2006) teori hirarki kebutuhan Maslow (1954) memberikan konsep yang cukup penting dan dapat digunakan hingga saat ini. Luthans (2006) menambahkan bahwa poin penting dari teori Maslow (1954) tidak terletak pada jumlah dan nama tingkat maupun konsep hierarki, tetapi terletak pada fakta bahwa karyawan di tempat kerja mempunyai motivasi yang berbeda, beberapa diantaranya mempunyai motivasi tingkat tinggi.

Berdasarkan teori ini maka untuk memotivasi tim audit, pimpinan perlu memahami bahwa kebutuhan tim audit tidak terbatas pada kebutuhan pada tingkat dasar, tetapi dapat pula berada pada tingkat yang lebih tinggi. Luthans (2006) menyimpulkan teori hirarki kebutuhan Maslow bahwa jika satu tingkat kebutuhan dipenuhi, tingkat tersebut tidak memotivasi lagi. Tingkat kebutuhan yang lebih tinggi berikutnya diaktifkan untuk memotivasi individu. Ini artinya, pekerjaan audit adalah pekerjaan tim dimana anggota tim audit merupakan bagian yang tak terpisahkan dari organisasi sehingga membutuhkan penerimaan dari supervisor berupa tindakan supervisi yang efektif. Kebutuhan ini merupakan kebutuhan tingkat ketiga.

Demikan halnya dengan kompleksitas tugas dan profesionalisme yang merupakan karakteristik pekerjaan audit. Karakteristik ini menjadi tantangan bagi tim audit untuk memaksimalkan kemampuan agar berprestasi dalam menyelesaikan tugas audit. Kebutuhan berprestasi juga berada pada kebutuhan tingkat ketiga. Dengan mengidentifikasi kebutuhan-kebutuhan tersebut, pimpinan dapat mengoptimalkan usahanya untuk membentuk tim audit yang solid sehingga mendukung tercapainya tujuan organisasi, yaitu peningkatan kapabilitas fungsi pengawasan.

\section{Kepuasan Kerja Auditor}

Seseorang dengan tingkat kepuasan kerja yang tinggi mempunyai sikap positif terhadap pekerjaannya, sebaliknya jika seseorang tidak puas dengan pekerjaannya mempunyai sikap negatif terhadap pekerjaannya (Robins, 2002). Luthans (2006) menyimpulkan tiga dimensi yang diterima secara umum dalam kepuasan kerja. Pertama, kepuasan kerja merupakan respons emosional terhadap situasi kerja. Kedua, kepuasan kerja sering ditentukan menurut seberapa baik hasil yang dicapai memenuhi atau melampaui harapan. Ketiga, kepuasan kerja mewakili beberapa sikap yang berhubungan.

As'ad (2012) mengemukakan setiap individu akan memiliki tingkat kepuasan yang berbedabeda sesuai dengan sistem nilai-nilai yang berlaku padanya. Semakin banyak aspek-aspek dalam pekerjaan yang sesuai dengan keinginan individu tersebut, maka semakin tinggi tingkat kepuasan yang dirasakan, dan sebaliknya. Menurut Smith et al. (1969) terdapat lima dimensi kepuasan kerja yang meliputi: (1) pekerjaan itu sendiri; (2) gaji; (3) kesempatan promosi; (4) pengawasan; dan (5) rekan kerja. Luthans (2006) menambahkan kondisi kerja sebagai dimensi yang penting dari kepuasan kerja sebagai akibat dari diversitas tenaga kerja yang meningkat.

\section{Pengaruh Tindakan Supervisi Terhadap Kepuasan Kerja Auditor}

BPKP (2008) menyebutkan supervisi audit merupakan salah satu aktivitas manajerial yang berfungsi untuk melakukan pengawasan, pengontrolan atau penyeliaan atas penugasan audit agar tujuan audit dapat dicapai dengan ekonomis, efektif, dan efisien untuk memberikan rekomen- 
dasi perbaikan kinerja auditan. Permenpan nomor 19 tahun 2009 tentang pedoman kendali mutu audit APIP menyatakan bahwa terdapat tiga jenis supervisi dalam APIP, yaitu supervisi oleh pengendali mutu, supervisi oleh pengendali teknis dan supervisi oleh ketua tim.

Tindakan supervisi biasanya dilaksanakan oleh pimpinan suatu organisasi. Tindakan supervisi meliputi seluruh aspek yang dijalankan oleh seorang pemimpin. Goleman et al. (2006) mengemukakan pemimpin menggerakkan, membangkitkan semangat dan menginspirasi yang terbaik bagi bawahannya. Tindakan supervisi yang direkomendasikan oleh Lembaga Akuntan Amerika yaitu Accounting Education Chage Commission (AECC) meliputi tiga hal: (1) penyediaan kepemimpinan yang kuat dan mentoring terhadap anggota staf; (2) menciptakan kondisi kerja yang kondusif untuk mencapai kesuksesan; dan (3) menyediakan penugasan yang memantang dan memperkirakan penyelesaian.

Menurut Luthans (2006) supervisi merupakan sumber penting dari kepuasan kerja. Salah satu penyebab ketidakpuasan karyawan adalah hubungan penyelia dan bawahan yang buruk (Firchman, 1998). Tindakan supervisi yang efektif ditujukan sebagai bentuk kepedulian supervisor kepada bawahannya. Sebagaimana disebutkan dalam tingkat kebutuhan Maslow bahwa setiap individu memiliki kebutuhan sosial, yaitu keinginan untuk dihargai dan diterima sebagai bagian dari organisasi. Tindakan supervisi yang efektif harus mampu membangkitkan kegembiraan, optimisme, dan gairah dalam melaksanakan pekerjaan, serta menumbuhkan atmosfer kerjasama dan kepercayaan. Dengan adanya tindakan supervisi yang efektif akan mampu menumbuhkan kepuasan karyawan terhadap pekerjaanya. Selain itu, tindakan supervisi yang efektif merupakan faktor penting yang dapat membantu memecahkan masalah yang muncul. Jika tindakan supervisi dilaksanakan secara efektif, akan berpengaruh positif terhadap kepuasan kerja (Murtanto dan Djasmin, 2005).

Adanya supervisi dapat meningkatkan kepuasan anggota suatu organisasi. Sebagaimana dikemukakan Yusralaini et al. (2011) bahwa untuk meningkatkan kepuasan kerja auditor, tindakan supervisi merupakan hal yang perlu untuk diperhatikan, baik dari aspek kepemimpinan dan mentoring, kondisi kerja, serta penugasan. Hal ini akan menunjang produktivitas kinerja auditor dalam pelaksanaan tugas, karena kepuasan kerja sangat mempengaruhi produktivitas kerja. Selan- jutnya, Boiman et al. (2013) menyebutkan bahwa pimpinan ataupun inspektur perlu memperhatikan aspek kepemimpinan dan mentoring sehingga dapat memberikan pengaruh terhadap efektivitas kerja auditor internal Inspektorat.

Syofyetty (2009) serta Boiman et al. (2011) menemukan bukti empiris bahwa secara positif aspek kepemimpinan dan mentoring, kondisi kerja, serta penugasan mampu mempengaruhi kepuasan kerja auditor. Murtanto dan Djasmin (2005) menemukan kondisi kerja berpengaruh terhadap kepuasan kerja. Demikian pula dengan Hadi (2007) yang menyimpulkan bahwa aspek kepemimpinan dan mentoring berpengaruh positif signifikan terhadap kepuasan kerja. Berdasarkan uraian di atas, dapat disimpulkan bahwa tindakan supervisi yang efektif diperlukan untuk menumbuhkan semangat melalui keteladanan, contoh, arahan, bimbingan, kondisi kerja yang kondusif, dan penugasan yang tepat sehingga tercipta tim audit yang solid. Tim audit yang saling percaya dan saling bekerjasama satu sama lain sehingga dapat meningkatkan kepuasan auditor terhadap pekerjaan auditnya. Oleh karena itu, hipotesis pertama yang diajukan penulis adalah :

H1: Tindakan supervisi berpengaruh positif terhadap kepuasan kerja auditor

\section{Pengaruh Kompleksitas Tugas Terhadap Kepuasan Kerja Auditor}

Engko dan Gudono (2007) mendefinisikan kompleksitas tugas audit sebagai tugas yang kompleks, terdiri atas bagian-bagian yang banyak, berbeda-beda dan saling terkait satu sama lain. Fitriany et al. (2010) menyebutkan salah satu faktor yang mempengaruhi kualitas kerja adalah kompleksitas penugasan. Folami dan Bline (2012) menjelaskan variasi tugas dibutuhkan pekerjaan untuk menyelesaikan berbagai aktivitas yang berbeda. Pekerjaan yang banyak akan memerlukan sejumlah keterampilan yang berbeda dan bakat dari seseorang. Folami dan Bline (2012) menambahkan bahwa penggunaan keterampilan yang berbeda dan bakat membantu mempertahankan produktivitas selama periode yang lama. Pekerjaan dengan tugas yang tinggi mempertahankan kepentingan karyawan, sehingga mengarah pada peningkatan kepuasan kerja.

Teori hirarki kebutuhan Maslow menentukan apa yang memotivasi orang dalam pekerjaan. Salah satu hal yang memotivasi tersebut adalah keinginan akan kebutuhan untuk berprestasi. Luthans (2006) mengemukakan bahwa 
karyawan dengan tingkat prestasi/pencapaian tinggi menganggap penyelesaian tugas merupakan hal yang menyenangkan secara pribadi, karyawan tersebut tidak mengharapkan atau menginginkan penghargaan material. Berkaitan dengan hal tersebut, tugas audit yang kompleks, terdiri atas bagian-bagian yang banyak, berbeda-beda dan saling terkait satu sama lain (Engko dan Gudono, 2007) jika dapat diselesaikan oleh tim audit maka akan menjadi sumber kepuasan. Judge et al., (2000) mengemukakan bahwa karakteristik pekerjaan dan kompleksitas pekerjaan menghubungkan antara kepribadian dan kepuasan kerja. Jika persyaratan kreatif pekerjaan karyawan terpenuhi, maka karyawan cenderung menjadi puas (Shalley et al., 2000). Hal ini berarti bahwa penyelesaian tugas dengan kompleksitas yang tinggi dapat menjadi prestasi yang menyenangkan bagi auditor internal.

Hasil penelitian Pradipta (2013) menemukan bukti empiris bahwa kompleksitas tugas audit mampu mempengaruhi kepuasan kerja auditor secara positif. Bahkan Folami dan Bline (2012) menemukan bahwa kompleksitas tugas audit memiliki pengaruh positif signifikan terhadap kepuasan auditor. Auditor yang memiliki tingkat kompleksitas tugas yang tinggi diikuti dengan meningkatnya kepuasan kerja yang dirasakan. Sementara Fitriany et al. (2010) tidak menemukan adanya pengaruh kompleksitas tugas terhadap kepuasan kerja auditor. Menurut Fitriany et al. (2010) auditor sudah terbiasa berhadapan dengan tingginya kompleksitas tugas audit sehingga tidak berpengaruh terhadap kepuasan kerja.

Berdasarkan uraian diatas, dapat disimpulkan bahwa kompleksitas yang timbul dari perubahan paradigma audit memerlukan perubahan teknik, metode dan prosedur audit yang lebih rumit. Hal tersebut akan menjadi tantangan sekaligus daya tarik yang menjadi sumber semangat auditor internal untuk menggunakan seluruh kemampuannya dalam menyelesaikan pekerjaan audit. Bagi auditor, penyelesaian kerumitan tugas akan menjadi prestasi yang menyenangkan. Oleh karena itu, hipotesis kedua yang diajukan penulis adalah:

H2: Kompleksitas tugas berpengaruh positif terhadap kepuasan kerja auditor

\section{Pengaruh Profesionalisme Auditor Terhadap Kepuasan Kerja Auditor}

Kamus Webster Amerika dalam Anoraga (1998) menegaskan bahwa profesionalisme adalah suatu tingkah laku, suatu tujuan atau rangkaian kualitas yang menandai atau melukiskan coraknya suatu profesi. Pentingnya sikap profesionalisme disebutkan dalam Standar Pemeriksaan Keuangan Negara (SPKN) nomor 1 tahun 2007 bahwa dalam melaksanakan tanggung jawab profesionalnya, pemeriksa harus memahami prinsipprinsip pelayanan kepentingan publik serta menjunjung tinggi integritas, obyektivitas, dan independensi. Pemeriksa harus memiliki sikap untuk melayani kepentingan publik, menghargai dan memelihara kepercayaan publik, dan mempertahankan profesionalisme.

Dali dan Mas'ud (2014) mengemukakan konsep profesionalisme digunakan untuk mengukur bagaimana para professional melihat profesinya yang tercermin dari sikap dan perilaku. Untuk menjaga dan menumbuhkan sikap profesional, dalam standar audit disebutkan bahwa seorang auditor berkewajiban mengikuti standar audit dan meningkatkan kemampuannya. Dali dan Mas'ud (2014) menambahkan profesionalisme sebagai masalah penting bagi auditor. Konsep profesionalisme digunakan untuk mengukur bagaimana profesional menjalankan profesinya yang tercermin dari sikap dan perilaku auditor. Agustia (2007) menyimpulkan seorang profesional adalah seseorang yang (1) percaya bahwa pekerjaanya adalah penting (dedication); (2) memberikan jasa bagi kepentingan publik (social obligation); (3) memerlukan otonomi sebagai syarat bagi jasa-jasa auditor (autonomy demand); (4) mendukung peraturan tersendiri yang berbeda dengan aturan profesi yang lain (belief in self regulation); dan (5) berafiliasi dengan anggota-anggota lain dalam profesi auditor (community affiliation).

Pekerjaan audit merupakan profesi yang membutuhkan sikap profesional yang tinggi. Hal ini berkaitan dengan jasa yang ditanganinya menyangkut kepentingan publik. Semakin tinggi tingkatan auditor maka semakin tinggi tuntutan profesionalismenya. Profesionalisme merupakan salah satu karakteristik dari pekerjaan audit. Karakteristik ini dapat menjadi tantangan dan daya tarik tersendiri. Semakin mampu auditor meningkatkan profesionalisme menunjukkan bahwa auditor tersebut semakin puas dengan profesi yang dijalaninya. Kemampuan untuk bersikap profesional mencerminkan prestasi auditor tersebut. Sebagaimana teori Maslow menyatakan bahwa kebutuhan sosial merupakan salah satu kebutuhan yang melekat pada diri individu, yaitu keinginan untuk berprestasi. 
Berkaitan dengan hal tersebut di atas, Dali dan Mas'ud (2014), Agustia (2007), Putri (2011), serta Hernawati (2008) menyimpulkan bahwa profesionalisme mampu mempengaruhi kepuasan kerja. Berdasarkan uraian tersebut, dapat disimpulkan bahwa keberhasilan menjaga profesionalisme akan menciptakan iklim kerja untuk berprestasi sehingga mempengaruhi kepuasan kerja bagi auditor. Oleh karena itu, hipotesis ketiga yang diajukan penulis adalah:

H3: Profesionalisme auditor berpengaruh positif terhadap kepuasan kerja auditor

\section{METODE PENELITIAN}

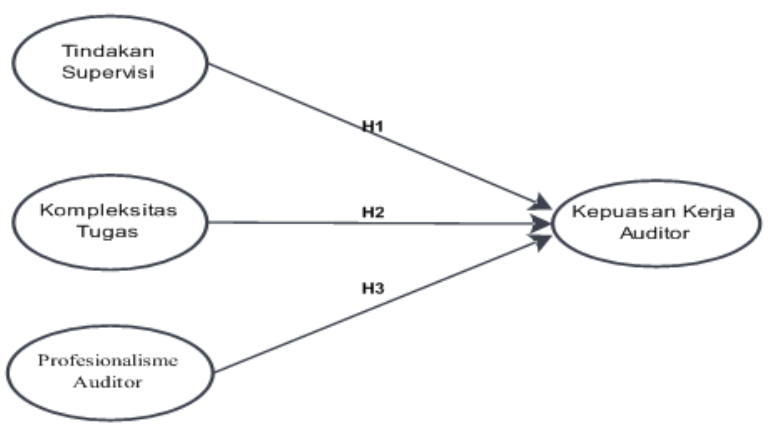

Gambar 1. Model Penelitian

\section{Populasi dan Sampel Penelitian}

Populasi dalam penelitian ini adalah auditor internal yang meliputi Pejabat Fungsional Auditor (JFA) dan Pejabat Pengawas Urusan Pemerintahan Daerah (P2UPD) yang melaksanakan fungsi pengawasan di kantor Inspektorat se-Pulau Sumbawa. Sampel penelitian ini ditentukan dengan menggunakan teknik purposive sampling, dengan kriteria sampel adalah auditor internal (JFA dan P2UPD) yang telah memiliki sertifikat auditor nternal dan menjadi auditor pelaksana (anggota tim) dalam setiap penugasan audit. Kriteria ini digunakan karena fokus penelitian terkait penilaian tim audit terhadap supervisornya (ketua tim audit dan pengendali teknis), sehingga jenjang auditor yang diambil adalah auditor pelaksana (anggota tim). Sehingga sampel dalam penelitian ini berjumlah 81 auditor internal sepulau Sumbawa yang terdiri dari 50 JFA dan 31 P2UPD.

\section{Teknik Pengumpulan Data}

Data yang digunakan dalam penelitian ini adalah data primer. Data primer diperoleh dan dikumpulkan dengan menggunakan kuisioner. Kuisioner penelitian berisi daftar pertanyaan yang disusun secara terstruktur dan bersifat tertutup. Kuisioner diserahkan langsung oleh peneliti kepada responden.

\section{Definisi Operasional Variabel Penelitian}

\section{Variabel Eksogen}

Variabel eksogen merupakan variabel yang tidak dipengaruhi/ditentukan variabel lain dalam suatu model. Variabel eksogen dalam penelitian ini ada tiga yaitu Tindakan Supervisi (TS), Kompleksitas Tugas (KT), dan Profesionalisme Auditor (PA). Berikut definisi operasional dari variabel-variabel tersebut.

\section{Tindakan Supervisi}

Tindakan Supervisi (TS) merupakan pemberian contoh keteladan, pengarahan, penciptaan kondisi kerja yang sehat, dan pengendalian mutu hasil audit yang dilakukan secara berjenjang dari pengendali mutu terhadap pengendali teknis, pengendali teknis terhadap ketua tim, dan ketua tim terhadap anggota tim. Pengukuran variabel ini mengadopsi instrumen yang dikembangkan Patten (1995) dengan 22 item pernyataan mengenai tiga dimensi yaitu Aspek Kepemimpinan dan Mentoring (AKM), Aspek Kondisi Kerja (AKK), dan Aspek Penugasan (AP). Skala pengukuran yang digunakan adalah skala likert 1-5 (Riduwan dan Akdon, 2007). Skor 1 ( STS = Sangat Tidak Setuju), Skor 2 (TS=Tidak Setuju), skor 3 $(\mathrm{N}=$ Netral), skor $4 \quad(\mathrm{~S}=\mathrm{Setuju})$, dan skor 5 ( $\mathrm{SS}=$ Sangat Setuju).

\section{Kompleksitas Tugas}

Kompleksitas Tugas (KT) audit merupakan tugas yang kompleks, terdiri atas bagian-bagian yang banyak, berbeda-beda dan saling terkait satu sama lain (Engko dan Gudono, 2007). Pengukuran variabel ini menggunakan instrumen yang digunakan Folami dan Bline (2012). Terdiri dari 7 item pertanyaan mengenai lima dimensi yaitu Identitas Tugas (IT), Otonomi Tugas (OT), Signifikansi Tugas (ST), Umpanbalik Tugas (UT), dan Variasi Tugas (VT). Skala pengukuran yang digunakan adalah skala likert 1-5 (Riduwan dan Akdon, 2007:16). Skor 1 ( SS = Sangat Sedikit), Skor 2 ( $\mathrm{S}=$ =Sedikit), skor 3 ( $\mathrm{C}=$ =Cukup), skor $4(\mathrm{~B}=$ Banyak), dan skor 5 ( $\mathrm{SB}=$ Sangat Banyak). 
Profesionalisme Auditor

Profesionalisme Auditor merupakan sikap dan prilaku seorang profesional untuk mematuhi nilai-nilai dan peraturan dalam profesinya. Profesionalisme diukur dengan menggunakan instrumen yang dikembangkan Hall (1966) terdiri dari 20 item pernyataan mengenai lima dimensi yaitu Afiliasi Komunitas (AK), Dedikasi Pada Profesi (DPP), Kewajiban Sosial (KS), Keyakinan terhadap Peraturan Sendiri (KTPS), dan Kebutuhan Untuk Mandiri (KUM).Skala pengukuran yang digunakan adalah skala likert 1-5 (Riduwan dan Akdon, 2007). Skor 1 ( STS = Sangat Tidak Setuju), Skor 2 (TS=Tidak Setuju), skor 3 (RR=Ragu-ragu),skor $4 \quad(S=$ Setuju $)$ dan skor 5 (SS=Sangat Setuju).

\section{Variabel Endogen}

Variabel endogen merupakan variabel yang dipengaruhi/ditentukan oleh variabel lain dalam suatu model. Variabel endogen dalam penelitian ini adalah Kepuasan Kerja Auditor (KKA). Berikut adalah definisi operasional variabel endogen penelitian ini.

\section{Kepuasan Kerja Auditor}

Kepuasan Kerja Auditor (KKA) merupakan perasaan auditor terhadap aspek-aspek yang melingkupi pekerjaannya. Variabel ini diukur dengan mengunakan 6 item pernyataan yang digunakan Wartini (2010) dan dimodifikasi peneliti menjadi 13 item pernyataan mengenai enam dimensi yaitu Gaji (GAJ), Kelompok Kerja (KELKER), Kondisi Kerja (KONKER), Pekerjaan itu sendiri (PEKERJ), Promosi (PROMS), dan Supervisi (SUPERV). Skala pengukuran yang digunakan adalah skala likert 1-5 (Riduwan dan Akdon, 2007). Skor 1 ( STS = Sangat Tidak Setuju), Skor 2 (TS=Tidak Setuju), skor 3 ( $\mathrm{N}=$ Netral), skor 4 ( $\mathrm{S}=$ Setuju), dan skor 5 (SS=Sangat Setuju).
Untuk menentukan nilai kategori dari hasil olah kuisioner dilakukan penilaian dengan menggunakan interval kelas dengan rumus: Interval kelas $=\frac{\text { Nilai tertinggi-nilai terendah }}{\text { Jumlah kelas }}$

Nilai tertinggi dalam penelitian ini adalah 5 dan nilai rendah adalah 1 yang berasal dari skala penilaian kuisioner, jumlah kelas adalah 5 , dengan demikian didapatkan :

$$
\text { Interval kelas }=\frac{5-1}{5}=0,8
$$

Dengan demikian, dapat diklasifikasikan kategori rentang nilai untuk setiap jawaban alternatif pada kuesioner sebagai panduan dalam mengelompokkan hasil penilaian dapat disimak di Tabel 1.

\section{Metode Analisis Data}

Data hasil kuisioner diolah dengan menggunakan bantuan aplikasi SmartPLS 2.0 M3. Pengujian model pengukuran (outer mode) dilakukan dengan uji validitas dan uji reliabilitas. Uji validitas meliputi, convergent validity dan discriminant validity. Ukuran refleksif individual dikatakan tinggi jika berkorelasi lebih dari 0,70 dengan konstruk yang ingin diukur. Namun demikian, untuk penelitian tahap awal dari pengembangan skala pengukuran nilai loading 0,5 sampai 0,6 dianggap cukup (Chin, 1998). Discriminat validity dinilai dengan cara membandingkan nilai square root of average varianceextrated (AVE) setiap konstruk dengan korelasi antara konstruk dengan konstruk lainnya dalam model. Nilai AVE direkomendasikan > 0,5 (Ghozali, 2008). Untuk mengukur reliabilitas suatu konstruk dengan indikator refleksif dapat dilakukan dengan dua cara yaitu dengan Cronbach's alpha dan Composite reliability dengan nilai > 0.70 (Latan dan Ghozali, 2012).

Tabel 1. Rentang Kriteria dan Kategori

\begin{tabular}{|c|c|c|c|c|c|}
\hline \multirow{2}{*}{ No } & \multirow{2}{*}{$\begin{array}{l}\text { Interval } \\
\text { Kriteria }\end{array}$} & \multicolumn{4}{|c|}{ Kategori Variabel } \\
\hline & & $\begin{array}{l}\text { Tindakan } \\
\text { Supervisi }\end{array}$ & $\begin{array}{c}\text { Kompleksitas } \\
\text { Tugas }\end{array}$ & $\begin{array}{c}\text { Profesionalisme } \\
\text { Auditor }\end{array}$ & $\begin{array}{c}\text { Kepuasan Kerja } \\
\text { Auditor }\end{array}$ \\
\hline 1. & $\geq 4,2$ & Sangat Setuju & Sangat Banyak & Sangat Setuju & Sangat Setuju \\
\hline 2. & $3,4 \mathrm{~s} / \mathrm{d}<4,2$ & Setuju & Banyak & Setuju & Setuju \\
\hline 3. & $2,6 \mathrm{~s} / \mathrm{d}<3,4$ & Netral & Cukup & Ragu-ragu & Netral \\
\hline 4. & $1,8 \mathrm{~s} / \mathrm{d}<2,6$ & Tidak Setuju & Sedikit & Tidak Setuju & Tidak Setuju \\
\hline 5. & $<1,8$ & Sangat Tidak Setuju & Sangat Sedikit & Sangat Tidak Setuju & Sangat Tidak Setuju \\
\hline
\end{tabular}


Adapun pengujian hipotesis (Inner Modeh) dilakukan dengan melihat nilai koefisien path atau innter model menunjukkan tingkat signifikansi dalam pengujian hipotesis. Skor koefisien path atau inner model yang ditunjukkan oleh nilai $\mathrm{T}$ statistic, harus lebih dari 1,664 karena penelitian ini menggunakan hipotesis satu arah (one-tailed) dengan taraf signifikansi $5 \%$.

\section{HASIL DAN PEMBAHASAN}

Dari Tabel 2 dapat diketahui bahwa dimensi variabel kepuasan kerja auditor yang memiliki skor rata-rata tertinggi adalah pekerjaan itu sendiri sebesar 4,05. Skor rata-rata dimensi kelompok kerja sebesar 4,00; dimensi supervisi sebesar 3,68; dimensi promosi sebesar 3,11; dimensi kondisi kerja sebesar 2,99; dan dimensi gaji memiliki skor rata-rata terendah sebesar 2,91. Hasil ini memberi makna bahwa responden sangat menyetujui bahwa audit merupakan pekerjaan yang menarik; menyetujui inspektur, pengendali teknis, dan ketua tim memiliki kemampuan supervisi yang memadai dengan kelompok kerja yang solid. Namun, responden bersikap netral terhadap sistem promosi, kondisi kerja, dan gaji sebagai auditor internal.

Dimensi variabel tindakan supervisi yang memiliki skor rata-rata tertinggi adalah aspek penugasan sebesar 3,84; aspek kondisi kerja sebesar 3,82 dan aspek kepemimpinan dan mentoring sebesar 3,62. Ketiga dimensi tersebut berada pada rentang nilai setuju. Hal ini berarti bahwa responden menyetujui bahwa secara keseluruhan tindakan supervisi yang dilakukan supervisor (pengendali mutu, pengendali teknis, dan ketua tim) telah efektif.

Dimensi variabel kompleksitas tugas yang memiliki skor rata-rata tertinggi adalah identitas tugas sebesar 3,38; otonomi tugas sebesar 3,33; umpan-balik tugas sebesar 3,28; signifikansi tugas 3,26 dan variasi tugas sebesar 3,20 . Hal ini berarti bahwa responden memiliki identitas, otonomi, umpanbalik, signifikansi dan variasi tugas yang cukup untuk menghadapi kompleksitas pekerjaan audit.

Dimensi variabel profesionalisme auditor yang memiliki skor rata-rata tertinggi adalah kebutuhan untuk mandiri sebesar 3,88; dimensi keyakinan terhadap peraturan sendiri sebesar 3,72; dedikasi pada profesi sebesar 3,38; kewajiban sosial sebesar 3,36 dan Afiliasi komunitas sebesar 3,21. Hal ini berarti bahwa responden memiliki keraguan untuk berafiliasi dengan anggota-anggota lain dalam profesi auditor, memiliki keraguan pekerjaannya adalah penting, dan memiliki keraguan jasa yang diberikan untuk kepentingan publik. Namun, responden menyetujui bahwa syarat bagi jasa-jasa

Tabel 2. Statistik Deskriptif

\begin{tabular}{|c|c|c|c|c|c|c|}
\hline Variabel & Dimensi Variabel & $\mathbf{N}$ & Min & Max & Mean & Std. Dev. \\
\hline \multirow{6}{*}{$\begin{array}{c}\text { Kepuasan Kerja } \\
\text { Auditor }\end{array}$} & Gaji & 81 & 1.50 & 4.00 & 2.91 & 0.75 \\
\hline & Kondisi Kerja & 81 & 1.25 & 4.50 & 2.99 & 0.83 \\
\hline & Supervisi & 81 & 2.33 & 5.00 & 3.68 & 0.61 \\
\hline & Kelompok Kerja & 81 & 2.00 & 5.00 & 4.00 & 0.54 \\
\hline & Promosi & 81 & 1.00 & 5.00 & 3.11 & 1.11 \\
\hline & Pekerjaan itu sendiri & 81 & 1.00 & 5.00 & 4.05 & 0.77 \\
\hline \multirow{3}{*}{ Tindakan Supervisi } & Aspek Kepemimpinan dan mentoring & 81 & 1.78 & 5.00 & 3.62 & 0.75 \\
\hline & Aspek Kondisi Kerja & 81 & 1.57 & 5.00 & 3.82 & 0.68 \\
\hline & Aspek Penugasan & 81 & 1.71 & 5.00 & 3.84 & 0.66 \\
\hline \multirow{5}{*}{ Kompleksitas Tugas } & Variasi Tugas & 81 & 2.00 & 4.50 & 3.20 & 0.52 \\
\hline & Identitas Tugas & 81 & 2.00 & 5.00 & 3.38 & 0.58 \\
\hline & Signifikansi Tugas & 81 & 1.00 & 5.00 & 3.26 & 0.72 \\
\hline & Otonomi Tugas & 81 & 1.00 & 5.00 & 3.33 & 0.77 \\
\hline & Umpanbalik Tugas & 81 & 2.00 & 4.50 & 3.28 & 0.54 \\
\hline \multirow{5}{*}{$\begin{array}{c}\text { Profesionalisme } \\
\text { Auditor }\end{array}$} & Afiliasi Komunitas & 81 & 1.75 & 4.75 & 3.21 & 0.68 \\
\hline & Kebutuhan untuk mandiri & 81 & 3.00 & 4.75 & 3.88 & 0.44 \\
\hline & Keyakinan terhadap peraturan sendiri & 81 & 2.75 & 4.75 & 3.72 & 0.41 \\
\hline & Dedikasi pada profesi & 81 & 2.25 & 4.50 & 3.38 & 0.49 \\
\hline & Kewajiban sosial & 81 & 2.00 & 4.50 & 3.36 & 0.45 \\
\hline
\end{tabular}


auditor memerlukan otonomi dan menyetujui bahwa peraturan sendiri berbeda dengan aturan profesi yang lain.

Berdasarkan Gambar Path diagram (lihat Gambar 2) dapat dilihat bahwa variabel telah memiliki nilai loading factor $>0,70$ yang berarti bahwa semua indikator dimensi variabel adalah valid. Begitu juga pada nilai AVE, dan Communality yang dihasilkan oleh semua dimensi variabel yakni $>0,50$ sehingga memenuhi persyaratan validitas konvergen. Dengan nilai akar
AVE lebih besar dari nilai korelasi variabel laten sehingga memenuhi persyaratanvaliditas diskriminan. Nilai Composite Reliability yang dihasilkan semua dimensi variabel sangat baik yaitu di atas > 0,70, sehingga dapat disimpulkan bahwa semua indikator dimensi variabel adalah reliabel atau memenuhi uji reliabilitas. Dengan demikian dapat disimpulkan secara keseluruhan data penelitian validdan reliabel. Sebagaimana ditunjukkan pada Tabel 3 (Sofyani dan Akbar, 2013; 2015; Erimalata, 2016; Irfan et al., 2016).

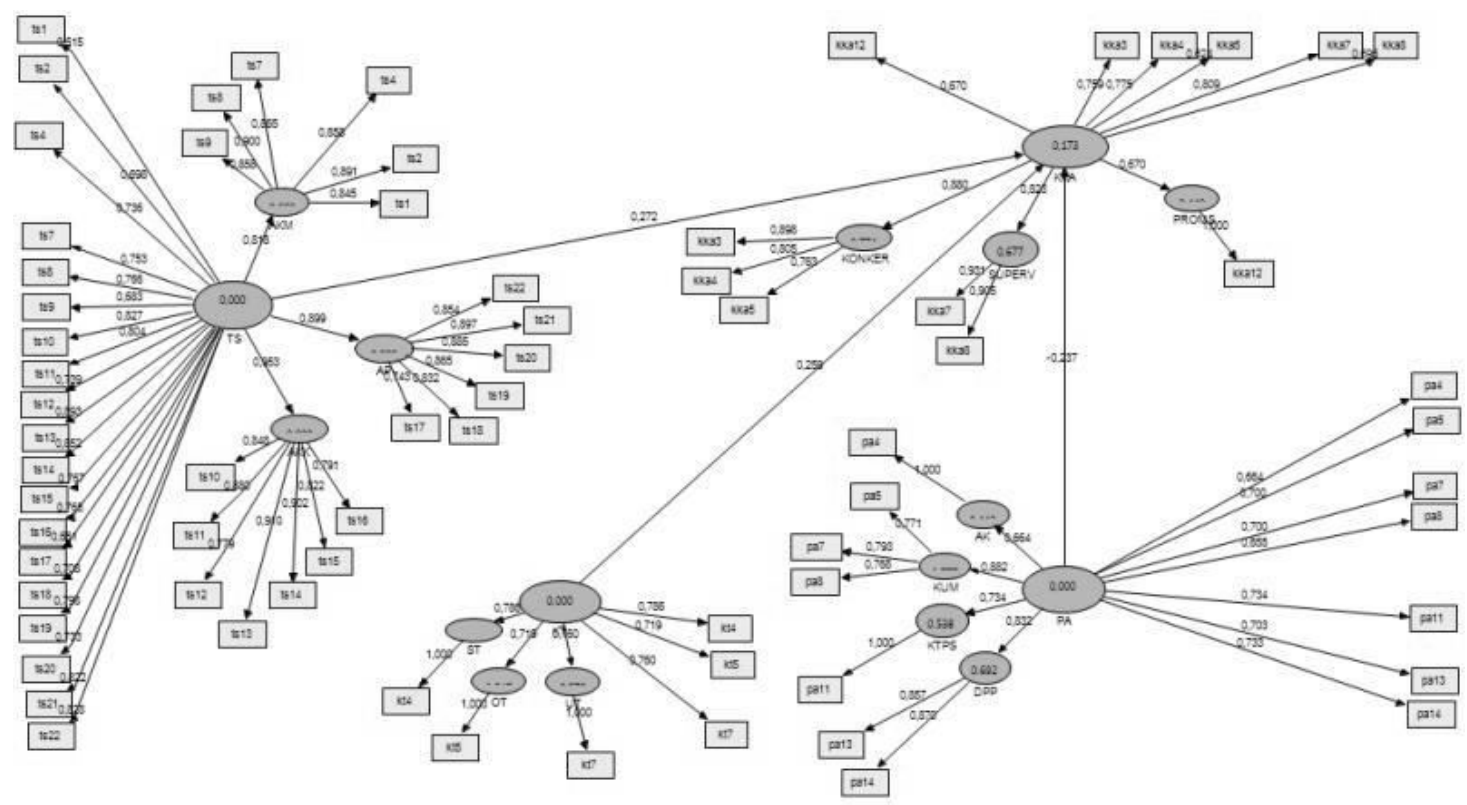

Gambar 2. Path diagram

Tabel 3. AVE, Communality dan Composite Reliability

\begin{tabular}{lccc}
\hline \multicolumn{1}{c}{ Dimensi Variabel } & AVE & Communality & Composite Reliability \\
\hline Aspek Kepemimpinan dan Mentoring (AKM) & 0,663990 & 0,663990 & 0,946319 \\
Aspek Kondisi Kerja (AKK) & 0,720328 & 0,720328 & 0,947286 \\
Aspek Penugasan (AP) & 0,718383 & 0,718383 & 0,938468 \\
Identitas Tugas (IT) & 1,000000 & 1,000000 & 1,000000 \\
Otonomi Tugas (OT) & 1,000000 & 1,000000 & 1,0000000 \\
Signifikansi Tugas (ST) & 1,000000 & 1,000000 & 1,000000 \\
Umpanbalik Tugas (UT) & 0,658936 & 0,658936 & 0,794208 \\
Variasi Tugas (VT) & 0,577410 & 0,577410 & 0,731144 \\
Afiliasi Komunitas (AK) & 1,000000 & 1,000000 & 1,000000 \\
Dedikasi Pada Profesi (DPP) & 0,745743 & 0,745743 & 0,854353 \\
Kewajiban Sosial (KS) & 1,000000 & 1,000000 & 1,0000000 \\
Kepercayaan Terhadap Peraturan Sendiri (KTPS) & 0,634033 & 0,634033 & 0,775052 \\
Kebutuhan Untuk Mandiri (KUM) & 0,550651 & 0,550651 & 0,829980 \\
Gaji (GAJ) & 0,744497 & 0,744497 & 0,852782 \\
Kelompok Kerja (KELKER) & 0,895299 & 0,895299 & 0,944751 \\
Kondisi Kerja (KONKER) & 0,615560 & 0,615560 & 0,863610 \\
Pekerjaan itu sendiri (PEKERJ) & 1,000000 & 1,000000 & 1,000000 \\
Promosi (PROMS) & 1,000000 & 1,000000 & 1,000000 \\
Supervisi (SUPERV) & 0,842965 & 0,842965 & 0,914782 \\
\hline
\end{tabular}


Tabel 4. Ringkasan Hasil Uji Hipotesis

\begin{tabular}{|c|c|c|c|c|}
\hline Hipotesis & Koefesien & T-Statistik & T-Tabel & Kesimpulan \\
\hline $\begin{array}{l}\text { H1 : Tindakan supervisi berpengaruh positif } \\
\text { terhadap kepuasan kerja auditor }\end{array}$ & 0,356452 & 2,775935 & 1,665 & H1 diterima \\
\hline $\begin{aligned} \text { H2 : Kompleksitas tugas berpengaruh positif } \\
\\
\text { terhadap kepuasan kerja auditor }\end{aligned}$ & 0,284559 & 3,044754 & 1,665 & H2 diterima \\
\hline $\begin{aligned} \text { H3 : Profesionalisme auditor berpengaruh } \\
\\
\text { positif terhadap kepuaan kerja auditor }\end{aligned}$ & $-(0,367818$ & 2,665253 & 1,665 & H3 ditolak \\
\hline
\end{tabular}

Setelah melakukan prosedur Bootstrapping data penelitian pada SmartPLS 2.0 M3, maka diperoleh hasil estimasi t-statistik variabel penelitian sebagaimana tercantum pada Tabel 4 dibawah ringkasan hasil uji hipotesis. Berdasarkan Tabel 4 untuk analisis hasil pengujian terhadap tiga hipotesis yang telah diajukan dapat dijelaskan bahwa hipotesis pertama (H1) menyatakan Tindakan Supervisi (TS) berpengaruh positif terhadap Kepuasan Kerja Auditor (KKA). Hasil uji nilai koefisien parameter antara variabel tindakan supervisi dan kepuasan kerja menunjukkan hubungan positif sebesar 0,356452 dengan nilai t-statistik 2,775935> 1,665 (t-tabel) dan signifikan pada taraf 5\% yang berarti bahwa tindakan supervisi berpengaruh positif signifikan terhadap kepuasan kerja auditor (KKA). Dengan demikian penelitian ini menerima $\mathrm{H} 1$.

Hasil analisis data menemukan bahwa Aspek Kepemimpinan dan Mentoring (AKM), Aspek Kondisi Kerja (AKK), dan Aspek Penugasan (AP) yang membentuk Tindakan Supervisi (TS) telah mampu mempengaruhi kepuasan kerja anggota tim auditnya. Selain itu, hasil penelitian ini menunjukkan bukti bahwa auditor internal yang memiliki masa kerja 1-5 tahun merupakan masa kerja awal yang mana pengetahuan dan pengalaman yang dimiliki masih belum memadai. Auditor dengan masa kerja ini membutuhkan arahan mengenai teknik menganalisis dan cara mengumpulkan data pemeriksaan. Sementara auditor dengan masa kerja lebih dari 5 tahun dapat dianggap sebagai auditor berpengalaman namun tetap membutuhkan arahan mengenai pokok-pokok lingkup pekerjaan pemeriksaan.

Semakin kondusif suasana kerja yang diciptakan supervisor, maka akan semakin meningkatkan rasa aman dan anggota tim dalam menyelesaikan tugas audit. Rasa aman dalam bekerja dan merasa dianggap sebagai bagian dari organisasi merupakan kebutuhan yang berpengaruh terhadap kepuasan kerja auditor. Hal ini sesuai dengan teori hirarki kebutuhan Maslow bahwa setiap individu membutuhkan rasa aman dalam bekerja dan kebutuhan diterima oleh orang lain tem- patnya bekerja. Dengan demkian, hasil penelitian ini mendukung dan sejalan dengan penelitian Syofyetty (2009). Di sisi lain, hasil penelitian ini berbeda dengan penelitian yang dilakukan Yusralaini et al. (2011), Murtanto dan Djasmin (2013), serta Boiman et al. (2013) yang menemukan bahwa aspek kondisi kerja dan penugasan audit yang berpengaruh terhadap kepuasan kerja. Sementara tindakan supervisi dari aspek kepemimpinan dan mentoring tidak berpengaruh signifikan.

Hipotesis kedua (H2) menyatakan bahwa Kompleksitas Tugas (KT) berpengaruh positif terhadap Kepuasan Kerja Auditor (KKA). Hasil uji nilai koefisien parameter antara variabel kompleksitas tugas dan kepuasan kerja menunjukkan hubungan positif sebesar 0,284559 dengan nilai t-statistik 3,044754 > 1,665 dan signifikan pada taraf $5 \%$ yang berarti bahwa kompleksitas tugas berpengaruh positif signifikan terhadap kepuasan kerja auditor (KKA). Semakin tinggi kompleksitas tugas audit yang dihadapi, maka semakin tinggi pula kepuasan anggota tim audit untuk menyelesaikan tugas tersebut. Dengan demikian penelitian ini menerima $\mathrm{H} 2$.

Hasil ini menemukan bukti bahwa adanya kompleksitas dalam tugas audit mampu mempengaruhi kepuasan kerja auditor internal pemerintah. Ini artinya empat dimensi yang membentuk Kompleksitas Tugas (KT) yaitu Variasi Tugas (VT), Otonomi Tugas (OT), Signifikansi Tugas (ST), dan Umpanbalik Tugas (UT) berpengaruh terhadap Kepuasan Kerja Auditor (KKA). Dengan demikian, tanggungjawab pekerjaan audit yang diserahkan supervisor telah disesuaikan dengan kemampuan anggota tim. Adanya keseimbangan tugas, kemampuan auditor dan umpanbalik yang diberikan supervisor dapat membantu auditor untuk menyelesaikan tugas auditnya, sehingga kompleksitas dalam tugas audit tetap menjadi daya tarik yang tidak menurunkan kepuasan kerja auditor. Artinya, jika tanggungjawab yang diberikan melebihi kemampuan auditor, maka dapat mengurangi tingkat kepuasan kerjanya. Sebagaimana kesimpulan Dewi dan Sukirno 
(2013) bahwa penugasan menjadi hal yang biasa bagi auditor, tetapi semakin banyak dan kompleknya tugas yang diberikan, maka akan berdampak pada menurunnya kepuasan kerja yang dirasakan auditor.

Hasil penelitian ini juga menunjukkan bahwa kompleksitas diperlukan sebagai tantangan auditor untuk menggunakan segala keahlian yang dimiliki. Penyelesaian tugas dengan tingkat kerumitan tertentu dapat menjadi prestasi yang menyenangkan bagi seorang auditor. Teori hirarki kebutuhan Maslow menentukan apa yang memotivasi orang dalam pekerjaan. Salah satu hal yang memotivasi tersebut adalah keinginan akan kebutuhan untuk berprestasi. Luthans (2006) mengemukakan karyawan dengan tingkat prestasi atau pencapaian tinggi menganggap penyelesaian tugas merupakan hal yang menyenangkan secara pribadi, dan karyawan tersebut tidak mengharapkan atau menginginkan penghargaan material. Dengan demikian, hasil ini sejalan dengan penelitian yang dilakukan Lookman dan Bline (2012) serta Pradipta (2013) yang menemukan bahwa kompleksitas tugas mempunyai pengaruh yang kuat terhadap kepuasan kerja.

Hasil ini berbeda dengan penelitian yang dilakukan Fitriany et al. (2010) yang menemukan bahwa kompleksitas tugas audit tidak berpengaruh terhadap kepuasan kerja auditor di Kantor Akuntan Publik (KAP). Hal itu disebabkan karena auditor pada KAP telah terbiasa menghadapi tingginya kompleksitas tugas audit sehingga tidak berpengaruh terhadap kepuasan kerjanya. Serta penelitian Dewi dan Sukirno (2013) yang menemukan bahwa kompleksitas berpengaruh negatif terhadap kepuasan.

Hipotesis ketiga (H3) menyatakan bahwa Profesionalisme Auditor (PA) berpengaruh positif terhadap Kepuasan Kerja Auditor (KKA). Hasil uji nilai koefisien parameter antara variabel Profesionalisme Auditor dan Kepuasan Kerja Auditor menunjukkan hubungan negatif sebesar $-0,367818$ dengan nilai t-statistik 2,665253> 1,665 dan signifikan pada taraf $5 \%$ yang berarti variabel Profesionalisme Auditor berpengaruh negatif signifikan terhadap kepuasan kerja auditor. Dengan demikian H3 dalam penelitian ini ditolak, dengan kata lain semakin tinggi tuntutan profesionalisme auditor maka akan menurunkan tingkat kepuasan kerja auditor, begitu pula sebaliknya.

Hal ini mungkin dapat disebabkan karena tingginya tuntutan untuk bersikap profesional kurang didukung dengan kemudahan untuk mengakses sarana dan prasarana, dalam rangka peningkatan profesionalisme auditor. Misalnya, keberadaan Asosiasi Auditor Internal Pemerintah Indonesia (AAIPI) yang baru dibentuk tahun 2012, menjadikan keberadaannya belum familiar bagi seluruh auditor internal yang berada di daerah-daerah. Selain itu, sistem Pendidikan dan Pelatihan (Diklat) untuk pengembangan kompetensi profesional masih terhambat sistem antrian yang panjang karena peserta berasal dari auditor internal seluruh Indonesia. Selain itu, minimnya pertemuan sesama profesi auditor yang diadakan di daerah, misalnya pertemuan melalui sosialisasi/ pelatihan dan pendidikan teknis tentang peraturan baru dan pengetahuan audit lain, yang dapat dijadikan sebagai ajang pertemuan auditor dari berbagai Inspektorat, bisa jadi juga turut menjadi alasan tidak terdukungnya hipotesis tiga ini. Dengan demikian, penelitian ini tidak berhasil mendukung teori kebutuhan Maslow bahwa pada tingkat tertentu individu memerlukan kebutuhan untuk berprestasi.

Hasil penelitian ini juga tidak mendukung penelitian yang dilakukan Aditya dan Wirakusuma (2014) yang menyimpulkan bahwa komitmen profesional yang diukur dengan lima indikator seperti dalam penelitian ini tidak berpengaruh terhadap kepuasan kerja auditor. Hal ini disebabkan karena komitmen profesional auditor sangat dipengaruhi oleh organisasi tempat auditor bekerja. Juga berbeda dengan hasil penelitian Dali dan Mas'ud (2014) yang menemukan bahwa profesionalisme auditor meningkatkan kepuasan kerja. Oleh karena itu, penelitian lebih lanjut dibutuhkan untuk memperkuat temuan dari penelitian ini.

\section{SIMPULAN}

Penelitian ini mengusulkan cara memotivasi tim audit dengan menggunakan konsep yang dibangun dengan teori hirarki kebutuhan Maslow. Analisis data menemukan bukti bahwa kebutuhan anggota tim audit Inspektorat ada pada tingkat ketiga yaitu kebutuhan sosial dan kebutuhan untuk berprestasi. Hal ini diperkuat dengan hasil penelitian yang menunjukkan tindakan supervisi berpengaruh positif dan signifikan terhadap kepuasan kerja auditor internal pemerintah, khususnya anggota tim audit. Ini artinya, semakin baik tindakan supervisi yang dilakukan supervisor akan semakin meningkatkan kepuasan kerja auditor. Hasil analisis lainnya menunjukkan 
bahwa kompleksitas tugas berpengaruh positif dan signifikan terhadap kepuasan kerja auditor internal pemerintah. Hal ini berarti kompleksitas yang melekat pada pekerjaan audit dapat menjadi daya tarik untuk mempengaruhi kepuasan kerja auditor.

Selama tugas dan tanggungjawab disesuaikan dengan kemampuan auditor, maka kompleksitas yang dihadapi auditor tidak akan mengurangi kepuasan kerjanya. Namun, penelitian ini tidak menemukan bukti pengaruh positif profesionalisme auditor terhadap kepuasan kerja auditor. Hal ini disebabkan oleh minimnya keyakinan dari auditor itu sendiri dan dukungan dari pihak lain untuk meningkatkan pengalaman, pengetahuan, dan kompetensi profesional auditor, sehingga tuntutan untuk makin profesionalisme dianggap sebagai beban yang dapat menurunkan kepuasan auditor terhadap profesi auditor internal.

Beberapa keterbatasan dalam penelitian ini yakni; pertama, ruang lingkup penelitian ini hanya terbatas pada Inspektorat se-Pulau Sumbawa, sehingga memungkinkan adanya perbedaan pada hasil penelitian dan kesimpulan jika ruang lingkup penelitian diperluas dengan menggunakan seluruh Inspektorat yang ada di Provinsi NTB. Kedua, penelitian ini berdasarkan persepsi auditor yang menjabat sebagai auditor pelaksana (anggota tim), hasil penelitian mungkin akan lebih baik jika menggunakan seluruh jenjang auditor. Ketiga, indikator yang digunakan untuk mengukur kompleksitas tugas belum bersifat universal sehingga tiap peneliti menggunakan indikator yang berbeda. Sementara penelitian ini menggunakan indikator yang dikembangkan untuk mengukur karakteristik pekerjaan. Meskipun hasil analisis menunjukkan pengaruh yang signifikan, tetapi indikator tersebut belum banyak digunakan untuk mengukur kompleksitas tugas.

Bagi penelitian selanjutnya dapat mengembangkan model penelitian ini dengan menambah atau mengganti variabel yang digunakan misalnya variabel motivasi, stress kerja, konflik, dan variabel lain yang berkaitan dengan kepuasan kerja auditor. Selain itu, penelitian selanjutnya juga dianjurkan untuk menambah responden dan memperluas lokasi penelitian agar hasil penelitian dapat digeneralisasi lebih luas. Terakhir, penelitian selanjutnya dapat menggunakan metode kualitatif untuk mendapatkan informasi yang lebih mendalam tentang faktor-faktor yang mempengaruhi kepuasan kerja yang berpengaruh terhadap kapabilitas fungsi pengawasan.

\section{DAFTAR PUSTAKA}

Aditya, D. G. A. A. dan M. G. Wirakusuma. 2014. Pengaruh Komitmen Profesional pada Kepuasan Kerja Auditor dengan Motivasi sebagai Variabel Moderasi. EJurnal Akuntansi Universitas Udayana, 6 (2), 210-222.

Agustia, D. 2007. Pengaruh Profesionalisme Auditor terhadap Job Satisfaction, Komitmen Organisasi dan Job Performance serta Turnover Intentions. Jurnal Media Mahrdhika, 5 (3).

Anoraga, P. dan S. Suyati. 1995. Perilaku Keorganisasian. Jakarta: PT. Dunia Pustaka Jaya.

As'ad, M. 2012. Seri Ilmu Sumber Daya Manusia - Psikologi Industri. Edisi Keempat. Yogyakarta: Liberty.

Boiman, P. K. dan R. A. S. Surya. 2013. Analisis Pengaruh Pelaksanaan Supervisi terhadap Kepuasan Kerja Auditor Internal Inspektorat se-Provinsi Riau. Jurnal Ekonomi, 21 (1).

Badan Pengawasan Keuangan dan Pembangunan. 2015. Perwakilan Provinsi Nusa Tenggara Barat.

2008. Supervisi Audit : Diklat Pembentukan Auditor Pengendali Teknis. Pusat Pendidikan dan Pelatihan Pengawasan BPKP.

2013. Penguatan Peran Auditor Intern terhadap Pengelolaan Keuangan Negara. Majalah Warta pengawasan BPKP, vol XX/no.3/September, 2013-ISSN.08540519.

Chin, W. W. 1998. The Partial Least Squares Approach for Structural Equation Modeling in Marcoulide, G. A. (Ed) Modern Method for Business Research. Mahwah. NJ. Erlbaum

Dali, N. dan A. Mas'ud. 2014. The Impact of Profesionalism, Locus of Control, and Job Satisfaction on Auditors' Performance : Indonesian Evidence. International Journal of Bussiness and Management Invention, 3, 63-73.

Dewi, D. D. dan Sukirno. 2013. Pengaruh Gaya Kepemimpinan, Kompleksitas Tugas, Time Budget Pressure, dan Komitmen Organisai terhadap Kepuasan Kerja Auditor pada KAP di Yogyakarta. Jurnal Nominal, 2 (2). 
Engko, C. dan Gudono. 2007. Pengaruh Kompleksitas Tugasdan Locus of Control Terhadap Hubungan antara Gaya Kepemimpinan dan Kepuasan Kerja Auditor. Paper Dipresentasikan Pada Simposium Nasional Akuntansi X, Makasar.

Fichman, M. 1988. Motivational Consequences of Absence and Attendance : Proportional Hazard Estimation of a Dynamic Motivation Model. Journal of Applied Psychology, 119-34.

Fitriany, et. al. 2010. Analisis Faktor yang Mempengaruhi Kepuasan Kerja Auditor dan Hubungannya dengan Kinerja dan Keinginan Berpindah Kerja Auditor. Paper Dipresentasikan Pada Simposium Nasional Akuntansi XIII, Purwokerto.

Folami, L. and D. Bline. 2012. Relationship Among Job Satisfaction, Task Complexity, and Organizational Context in Public. International Review of Business Research Papers, 8 (4), 207-224.

Ghozali, I. 2008. Structural Equation Modelling Metode Alternatif DenganPartial Least Square (PLS). Semarang: Badan Penerbit Universitas Diponegoro.

Erimalata, S. 2016. Pendekatan Hot-Fit Framework dalam Generalized Structural Component Analysis pada Sistem Informasi Manajemen Barang Milik Daerah: Sebuah Pengujian Efek Resiprokal. Jurnal Akuntansi dan Investasi, 17 (2), 141-157.

Goleman, D., R. Boyatzis, dan A. Mckee. 2006. Primal Leadership: Kepemimpinan Berdasarkan Kecerdasan Emosi. Jakarta: Gramedia.

Gibson, J. L., J. M. Ivancevich., dan J. H. Donnelly, Jr. 2002. Organisasi Perilaku Struktur dan Proses. Tangerang: Binarupa Aksara.

Hadi, S. 2007. Pengaruh Tindakan Supervisi terhadap Kepuasan Kerja Akuntan Pemula. JAAI, 2(2).

Hall, R. 1968. Profesionalisation and Bureaucratation. American Sosiological Review. 33, 92-104.

Hernawati, R. I. 2008. Pengaruh Profesionalisme terhadap Prestasi Kerja, Kepuasan Kerja, Komitmen Organisasi dan Keinginan Berpindah. Majalah Ilmiah Dian, 7(2).

Irfan, M., B. Santoso dan L. Effendi. 2016. Pengaruh Partisipasi Anggaran terhadap Senjangan Anggaran dengan Asimetri
Informasi, Penekanan Anggaran dan Komitmen Organisasional sebagai Variabel Pemoderasi. Jurnal Akuntansi dan Investasi, 17 (2), 158-175.

Latan, H. dan I. Ghozali. 2012. Partial Least Square (PLS) : Konsep, Teknik, dan Aplikasi SmartPLS 2.0M3. Semarang: Badan Penerbit Universitas Diponegoro.

Luthans, F. 2006. Perilaku Organisasi. Edisi Sepuluh. Yogyakarta: Penerbit Andi.

Murtanto dan M. Djasmin. 2005. The Correlation Analysis Between Supervisory Action and Organization Culture to Individual Performance of Junior Accountant in Publikc Accounting Firm with Job Satisfaction as Intervening Variable.The International Journal of Accounting and Bussines Society, 13 (2).

Patten, D. M. 1995. Supervisory Actions and Job Satisfaction: An Analysis of Differences Between Large and Small Public Accounting Firms. Accounting Horizons, 9 (2), 17-28.

Peraturan Badan Pemeriksa Keuangan Republik Indonesia nomor 1 tahun 2007 tentang Standar Pemeriksaan Keuangan Negara

Peraturan Menteri Pemberdayaan Aparatur Negara Nomor PER/05/M.PAN/03/2008 tentang Standar Audit Aparat Pengawasan Intern Pemerintah

Position and Issues Statements of the Accounting Education Change Commission. 1993. Issues Statement Number 4 Improving the Early Employment Experience of Accountants. AECC. com

Pradipta, A. 2013. Pengaruh Komitmen, Motivasi, Kompleksitas Tugas, dan Budaya Suportif Terhadap Kepuasan Kerja. www.stietrisakti.ac.id/MB/2013. Diakses tanggal 3 Maret 2015

Riduwan. A. 2005. Rumus dan Data Dalam Analisis Statistika Untuk Penelitian: Administrasi Pendidikan Bisnis Pemerintahan Sosial Kebijakan Ekonomi Hukum Manajemen Kesehatan. Bandung: Alfabeta.

Robbins, S. P. 2002. Prinsip-prinsip Perilaku Organisasi. Edisi 5. Jakarta: Erlangga.

Saari, M. L. and T. A. Judge. 2004. Employee Attitudes and Job Satisfaction. Journal Human Resource Management, 43 (4), 395-407.

Shalley, C. E., L. L. Gilson and T. C. Blum. 2000. Matching Creativity Requirements 
and the Work Environment: Effects on Satisfaction and Intentions to Leave. Academy of Management Journal, 43 (2), 215-223.

Smith, P.C., L. M. Kendall and C.L. Hulin. 1969. The Measurement of Satisfaction in Work and Retirement, Rand McNally, Chicago.

Sofyani, H., dan R. Akbar. 2013. Hubungan Faktor Internal Institusi dan Implementasi Sistem Akuntabilitas Kinerja Instansi Pemerintah (SAKIP) di Pemerintah Daerah. Jurnal Akuntansi dan Keuangan Indonesia, 10 (2), 184-205.

Sofyani, H. dan R. Akbar. 2015. Hubungan Karakteristik Pegawai Pemerintah Daerah dan Implementasi Sistem Pengukuran Kinerja: Perspektif Ismorfisma Institusional. Jurnal Akuntansi \& Auditing Indonesia, 19 (2), 153-173.

Sugiyono. 2013. Metode Penelitian Pendidikan Pendekatan Kualitatif, Kuantitatif, dan $R$ \& D. Cetakan 16. Bandung: Alfabeta.

Syofyetty, E. 2009. Pengaruh Tindakan Supervisi terhadap Kepuasan Kerja Auditor pada Inspektorat Provinsi Sumatera Barat. Tesis, Universitas Andalas.

Wartini, A. L. 2010. Pengaruh Komitmen Organisasional, Komitmen Profesional dan Motivasi Terhadap Kepuasan Kerja Auditor: Tesis, Universitas Gadjah Mada.

Yusralaini, R. A. dan Nelson Sinaga. 2011. Analisis Pengaruh Pelaksanaan Supervisi Terhadap Kepuasan Kerja Auditor BPKP Kantor Perwakilan Propinsi Riau. Jurnal Ekonomi, 19. 